\title{
有機溶剂洗浄と環境污染対策
}

\author{
間 宮 富 士 雄* \\ *日本シービー・ケミカル株式会社
}

\section{Organic Solvent Cleaning and Prevention of Environmental Contamination}

\author{
Fujio Mamiya*
}

* The Japan CeeBee Chemical Co., Ltd.

\begin{abstract}
As you know well, the kinds of organic solvent cleaning are various available and petroleum solvent cleaning, non-petroleum solvent cleaning, finger print removing and vapour degreasing are very popular methods. But, recently environmental contamination is very severe for restriction due to destroy of ozone by fron, etc. Therefore, this is mentioned for details of kinds for organic solvent cleaning and prevention of environmental contaminations.
\end{abstract}

Key words: solvent, cleaning, environment, contamination, prevention

\section{1.はじめに}

最近, 気象異常現象が起こりその要因としてフロン, 酸性雨, 温暖化などが話題となっている。そこで有機溶剂 (主として塩素系溶剤とフロン)による環境污染の問題を 取り上げ，有機溶剂による洗浄とこれに関連する環境污 染対策, 特にトリクロロエチレンおよびテトラクロロエ チレンが第 2 種特定化学物質に指定された関係上, これ に関する環境污染防止措置に関する指針を述べ，さらに フロン対策に伴らノンフロン型新溶剂の動向につき以下 解説する。

\section{2. 有機溶剤清浄の種類 ${ }^{1}$}

有機溶剂清浄の種類は, JIS Z 0303, さび止め包装方 法通則によれば次のごとき種類を規定している。以下， これらについて詳述してみる。

\section{1 石油系溶剂清浄方法}

JIS Z 0233，石油系溶剤清浄方法では次の方法が規定 されている。

\subsection{1 多段階清净方法}

機械加工中，付着した油脂類を除去する場合第一清浄 槽で下洗いし，第二，第三清浄槽で仕上げ洗いをする清 浄をいら。

\subsection{2 布ふき清浄方法}

浸せきあるいは吹付けができない場合は溶剤を含ませ た布で清浄にすることをいう。

\subsection{3 ブラシ掛け清浄方法}

污れが除去しにくい場合，溶剂に浸せきしながらブラ シでこすり清浄にすることをいう。

\subsection{4 スプレー清浄方法}

油脂, 金属細片などが付着している場合, 溶剂の溶解 力と噴射とで同時に清浄することをいう。

\subsection{5 超音波清浄方法}

より高度の清浄を要求する場合に, 超音波を与えて清 浄効果を向上させて清浄することをいう。

\subsection{6 二溶剤清浄方法}

溶剂に可溶性の有機質以外の汗, 指紋などの無機質の

* 干101 東京都千代田区岩本町 2-4-3 (2-4-3, Iwamotocho, Chiyoda-ku, Tokyo, 101 Japan) 著者紹介

工学院工業専門学校，工業化学科卒。金属の洗浄（含精密洗浄）および腐食抑制剂，金属の化成処理，防錆処 理に関する研究開発と関連公害対策に携わっている。金属部門 (表面処理技術) 技術士，経営工学部門 (包装) 技術士。日本技術士会，日本防錆技術協会，軽金属学会，表面技術協会アルミウニム表面処理技術部会に所属。 
污れが共存する場合、第一段で石油系溶剂を用いて有機 質の污れを清浄にし，第二段で指紋除去剤を用いて清浄 にすることをいら。

\subsection{7 組合せによる清浄方法}

これらの上記の清浄方法を組合也応用する清浄をい ら。以上の清浄方法に用いられる清浄剤である石油系溶 剤としては，JISZ 0233 では 1 種として引火点が $30^{\circ} \mathrm{C}$ 以上, 2 種として引火点が $50^{\circ} \mathrm{C}$ 以上 (スプレー清浄用) のものを使用することが規定されている。米国連邦規格 FS-P-D-680 では, ドライクリーニングソルベントが規 定されている。ドライクリーニングソルベントはストダ ードソルベント (stoddard solvent) ともいわれ, 酸, ア ルカリ白土吸着法で十分に精製され蒸留残椬も中性であ り，不揮発分はごく微量で銅に対して $\left(100^{\circ} \mathrm{C}, 3\right.$ h. $)$ の 影響は微変色以下であって金属の清浄に適している。引 火点はガソリンよりも高い。すなわち，第 1 種は最低 $37.7^{\circ} \mathrm{C}$, 第 2 種は最低 $58.9^{\circ} \mathrm{C}$ であるが，火災に対して は十分注意をしなければならない。

スプレー清浄の場合には, ドライクリーニングソルベ ントよりもさらに高い引火点の溶剤を使用することが安 全である。米軍規格 MIL-S-10561 では, Cleaning Solvent, High Temperature, Pressure Spray（引火点 79.4 ${ }^{\circ}$ C) が規定されている。

\section{2 石油系以外の溶剤清浄方法}

清浄方法としては 2.1 と同じであり, 使用される清浄 剂が石油系以外の溶剤といらことである。石油系溶剤以 外に使用される溶剂としては次のものがある。

\subsection{1 芳香族系溶郕}

これらの代表的なものとしては, ベンゼン, トルェン, キシレンなどがあるが, 臭気, 引火点, 毒性などの点か ら単独で使用されることは少ない。自動車の塗装ライン に打ける塗り換え作業に执いて塗料用配管や塗装用ガン の洗浄にこれらの溶剤をベースとした混合溶剤が多量に 使用されている。

\subsection{2 塩素系溶剤}

これらの代表的なものとしては,トリクロロエチレン, テトラクロロエチレン，1,1,1-トリクロロエタン，メチ レンクロライドなどがあり, 次の特長から広く利用され ている。

（1）不然性であるため火災の危険がない。

（2）油脂に対する溶解性が強く，脱脂性が大である。

（3）廃液を回収, 蒸留して再使用できるので経済的で ある。

（4）適当な装置を用いれば連続作業が容易である。

(5) 後処理としての乾燥を必要としない。

しかし，欠点としては次の事項が挙げられる。

（1）人体に対する毒性があること（但し装置が正しく
調整され正常に操作されれば危険はない)。

（2）加熱をするため, 熱に対する敏感性を有する有機 物, すなわち, 塗料, プラスチックなどを構成材料 としてもつ組立品には使用できない。

（3）水が存在すると腐食性の酸を生じるので, 定期的 にチェックする必要がある。

\subsection{3 フッ素系溶剤}

これらの代表的なものはフロン 113 であり，その特長 は次のと拈りである。

（1）フロン 113 は毒性が少なく安全性が高い。

(2) フロン 113 は酸やアルカリに対してきわめて安定 性が強くほとんど分解しない。

(3) プラスチックやエラストマーに対する影響がな W。

(4) フロン 113 の SP (Solubility Parameter) 值は 7.2 であり, 油污れの SP 值は8〜10であり, 近似のた め, 油污れはフロン 113 と混り合い洗浄が可能であ る。

（5）洗浄用以外にも乾燥用溶剤として利用出来る。 しかし, オゾン層破壊の問題により現在, 世界のフロン メーカーが競って新フロンの開発研究に当っている。

\section{3 汗および指紋除去方法}

石油系溶剂清浄または蒸気脱脂（後述）を行ったのち に,この方法が適用される。前記の清浄では, 汗や指紋 等の無機物残椬の除去が不可能であるからである。

JIS Z 0303 では, 指紋除去形さび止め油, メタノール などの指紋除去剤中に浸せきし，十分に振とうして汗お よび指紋を完全に除去する。な特，浸せきすることの出 来ない大きなものは, 指紋除去剤を含ませた布で清浄す ることを規定しているが, 米軍規格 MIL-P-116D には, 石油系溶剤を基剤としている指紋除去剤 (MIL-C-15074, Corrosion Preventive, Finger Print Remover) を適用 したあとで, 汗や指紋除去剤の残椬を洗い流すために, FS-P-D-680 または TT-T-291 などの石油系溶剤に浸せ きし，すすぎを行うよう指示している。すなわち，MIL はJISよりもさびしい処理を規定している。これはJIS K 2246, NP-O と MIL-C-15074 の性能上の差異, とく に防錆性能の差異によるか子知れないが, 特別に清浄性 を要求されるものについては MIL の考方方を考慮すべ きである。

\section{4 蒸気脱脂方法}

JIS Z 0303 ではハロゲン化炭化水素の蒸気に金属製品 をさらして清浄する。この方法は, 污れが油やグリース のよらなもののときに適用する。ただし, 金属製品が登 気で污損されるものや複雑な精密表面をもつものには不 適当であると規定されている。

溶剂脱脂の中で最も工業的意味をもつものは蒸気脱脂 


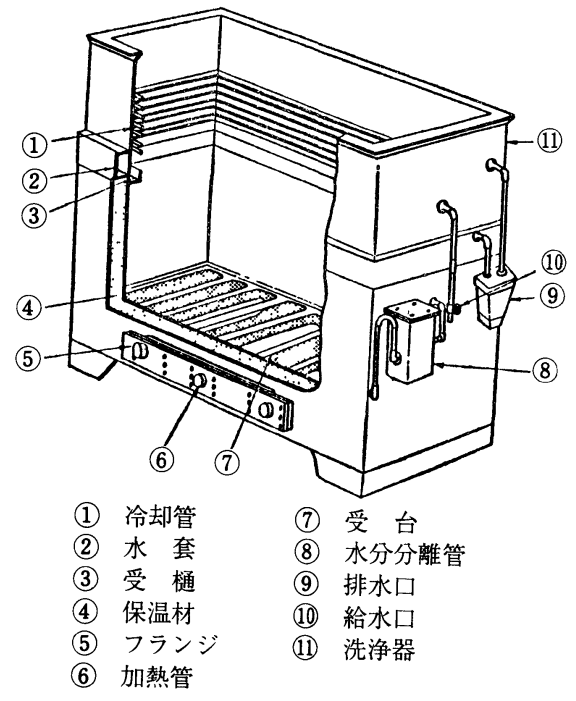

図 1 小型溶剂蒸気清浄槽

である。この原理は不燃性の塩素系溶剤を加熱させ, 気 相中に冷たい品物を保つと, 表面に凝縮した溶剤が油脂 を溶解して除去し，その際油脂と共に付着している塵埃 なども一緒に洗い执とされるわ忴である。品物は溶剂蒸 気の潜熱をらけて加熱され, 蒸気の温度まで温度が上昇 すると凝縮が終わり，とり出した品物の表面には溶剤が のこらず乾燥した状態のものがえられるので他の清浄法 と異なり乾燥の工程が省略できる利点がある。図 1 は小 型溶剂蒸気脱脂槽の図である。

蒸気脱脂法の操作にあたり溶剤の污れの程度を定期的 に点検して污れが $30 \%$ (油脂溶解量) をこえたら蒸留し て回収し，槽の中の溶剤を清浄にしなければならない。 表 1 に示すように溶剤中の油脂量に比例して沸点が上昇 するから，沸点の測定により污れの程度を判定すること ができる。

また, 清浄槽の気相中の遊離酸の濃度を点検する必要 がある。遊離酸の存在の有無は槽の内または槽周辺の特 有な刺激臭によりある程度判定出来るが，迅速で簡単な 検查法としては, 液化して貯蔵槽に還流する溶剂試料 $100 \mathrm{cc}$ をとり蒸留水 $100 \mathrm{cc}$ を加えてよく攪拌し，ガラ ス電極 $\mathrm{pH}$ 計により $\mathrm{pH}$ を測定し, もし $\mathrm{pH}$ が 5 以下 なら修正する必要がある。

最近では蒸気脱脂清浄にメチレンクロライドが毒性が 少ないこと，安定性にすぐれていること，長期間連続使 用できること, 再生効率がきわめて高いこと, 作業環境 が快適であること，溶解力が良いことなどから多用され ている。

かつ, メチレンクロライドの沸点が $40^{\circ} \mathrm{C}$ と低いため に加熱経費が節約できる。これはトリクロロエチレンと
表 1 油脂溶解量と沸点との関係

\begin{tabular}{|c|c|c|c|}
\hline $\begin{array}{c}\text { 鉱物油含有量 } \\
(\text { 容量 } \%)\end{array}$ & $\begin{array}{r}\text { 混合物の沸 } \\
\text { トリクロロエチレン }\end{array}$ & $\begin{array}{l}\text { 点 }\left({ }^{\circ} \mathrm{F}\right) \\
\text { テトラクロロエチレン }\end{array}$ & 備 考 \\
\hline 0 & $188.6\left(87^{\circ} \mathrm{C}\right)$ & $250.2\left(121.2^{\circ} \mathrm{C}\right)$ & \\
\hline 5 & $189.3(87.5)$ & 251.2 (121. 8) & i \\
\hline 10 & $190.6(88.1)$ & 252.3 (122. 4) & 脱 \\
\hline 15 & 191.7 (88.7) & 253.5 (123.1) & \multirow[t]{3}{*}{ 脂 } \\
\hline 20 & 193. $7(89.5)$ & 254.8 (123. 8) & \\
\hline 25 & $195.0(90.6)$ & 256.0 (124. 4) & \\
\hline 30 & 196.2 (91.2) & $196.2(125.6)$ & $\frac{1}{\text { 再 }}$ \\
\hline 35 & $198.5(92.5)$ & 198.5 (126.9) & 生 \\
\hline 40 & 201.2 (94.3) & 263.0 (128.3) & \multirow{2}{*}{$\begin{array}{c}\text { † } \\
\text { 蒸留限度 } \\
\downarrow \\
1\end{array}$} \\
\hline 45 & $204.8(96.0)$ & $266.0(130.0)$ & \\
\hline
\end{tabular}

比較すると $1 / 3$ 程度になりスタートアップの時間も大幅 に短縮することができる。しかしながら, 逆に清浄装置 の仕様や条件を一部改良する必要がある。すなわら, ト リクロロエチレンやテトラクロロエチレンの蒸気脱脂の 場合, 一般に冷却コイル（フリーボード）の深さは清浄 槽の幅の 50〜60\% であったが, メチレンクロライドの 場合にはフリーボードの深さを 80 〜 100\% に補強する 必要がある。

さらに, 製品の厚みが $2 \mathrm{~mm}$ 以下の品物を清浄する場 合には, その品物の表面に大気中の水分が結露すること があるので, このような場合には清浄槽の出口に乾燥機 の付設が必要である。

\section{5 超音波清净方法}

JIS Z 0303 では，溶剤または溶液中に金属製品を浸せ きし，超音波をかけて清浄する。この方法は細孔部など の污れを除去するのに適していると規定している。

超音波清浄に用いられる溶剤は従来, 石油系溶剤とく に白灯油が使用されていたが，最近ではこれに代わって 塩素系やフッ素系溶剤が多用されている。これらが用い られる原因としては, 次のような特性があるからである。

(1) 洗浄液が不燃性である。

引火点, 発火点がなく, したがって防爆対策の必要 がない。

(2) 表面張力が小さい。

表面張力が小さいことはキャビテーション強度を小 さくする。キャビテーションエネルギーは表面張力 の要因が大さいことが判明している。また, 表面張 力が小さいことは, 被洗浄物と接している空気と迅 速に置換し，ぬれを早くするので洗浄が早く出来 る。また，液切れがよく被洗浄物による溶剤のもち 出しロスが少ない。

(3) 比重が大きい。

水にくらべて, 約 1.3 1.5 倍も重く, その結果, ゴ ミや水分がよく浮くのでオーバーフローでの除去が 容易である。 
表 2 超音波洗浄用溶剂の特性值

\begin{tabular}{|c|c|c|c|c|c|}
\hline 溶 剤 名 称 & 分子式 & 比重 (20C) & 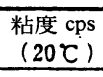 & $\begin{array}{c}\text { 表面張力 } \\
\text { dyne } / \mathrm{cm}\left(20^{\circ} \mathrm{C}\right)\end{array}$ & $\begin{array}{c}\text { 蒸気圧 } \\
\mathrm{mmH}(\mathrm{g}(20 \mathrm{C})\end{array}$ \\
\hline エチル・エーテル & $\left(\mathrm{C}_{2} \mathrm{H}_{5}\right)_{2} \mathrm{O}$ & 0.7135 & 0.245 & 17.0 & 440 \\
\hline アセトン & $\mathrm{CH}_{3} \cdot \mathrm{CO} \cdot \mathrm{CH}_{3}$ & 0.7911 & 0.326 & 23.7 & 185 \\
\hline 醋酸メチル & $\mathrm{CH}_{3} \cdot \mathrm{CO}_{2} \cdot \mathrm{CH}_{3}$ & 0.9272 & 0.381 & 24.6 & 160 \\
\hline メチル・エチル・ケトン & $\mathrm{CH}_{3} \cdot \mathrm{CO} \cdot \mathrm{C}_{2} \mathrm{H}_{5}$ & 0.8047 & 0.417 & 24.6 & 80 \\
\hline メチレンクロライド & $\mathrm{CH}_{2} \mathrm{Cl}_{2}$ & 1.326 & 0.425 & 28.2 & 349 \\
\hline 醋酸エチル & $\mathrm{CH}_{3} \cdot \mathrm{CO}_{2} \cdot \mathrm{C}_{2} \mathrm{H}_{5}$ & 0.9020 & 0.450 & 23.9 & 70 \\
\hline トリクロロエチレン & $\mathrm{CH} \cdot \mathrm{Cl}_{2}: \mathrm{CCl}_{2}$ & 1.464 & 0.580 & $29.0\left(30^{\circ} \mathrm{C}\right)$ & 58 \\
\hline トルエン & $\mathrm{C}_{6} \mathrm{H}_{5} \mathrm{CH}_{3}$ & 0.8658 & 0.580 & $30.0\left(26.7^{\circ} \mathrm{C}\right)$ & 22 \\
\hline メタノール & $\mathrm{CH}_{3} \cdot \mathrm{OH}$ & 0.7913 & 0.590 & 22.5 & 96 \\
\hline m-キシレン & $\mathrm{C}_{6} \mathrm{H}_{4}\left(\mathrm{OH}_{3}\right)_{2}$ & 0.8641 & 0.617 & 28.6 & 41 \\
\hline p-キシレン & $\mathrm{C}_{6} \mathrm{H}_{4}\left(\mathrm{OH}_{3}\right)_{2}$ & 0.8641 & 0.644 & 28.3 & 40 \\
\hline ベンゼン & $\mathrm{C}_{6} \mathrm{H}_{6}$ & 0.8794 & 0.654 & 29.0 & -76 \\
\hline フロンソルプまたはフレオン TF & $\mathrm{CCl}_{2} \mathrm{~F} \cdot \mathrm{CClF}_{2}$ & 1.572 & 0.701 & 18.0 & 272 \\
\hline 1.1.1 トリクロロエタン & $\mathrm{CH}_{3} \cdot \mathrm{CCl}_{3}$ & $1.325\left(26^{\circ} \mathrm{C}\right)$ & 0.790 & 25.6 & 100 \\
\hline o-キシレン & $\mathrm{C}_{6} \mathrm{H}_{4}\left(\mathrm{OH}_{3}\right)_{2}$ & 0.8802 & 0.809 & 30.0 & 45 \\
\hline バークロロエチレン & $\mathrm{CCl}_{2}: \mathrm{CCl}_{2}$ & 1.623 & 0.880 & 32.3 & 14 \\
\hline エタノール & $\mathrm{C}_{2} \mathrm{H}_{5} \cdot \mathrm{OH}$ & 0.7893 & 1.200 & 22.3 & 44 \\
\hline メチルセルソルプ & $\mathrm{CH}_{2} \cdot \mathrm{O}\left(\mathrm{CH}_{2}\right)_{2} \mathrm{OH}$ & 0.9663 & 1.720 & 35.0 & 9 \\
\hline セルソルプ & $\mathrm{C}_{2} \mathrm{H}_{5} \mathrm{O}\left(\mathrm{CH}_{2}\right)_{2} \mathrm{OH}$ & 0.9311 & 2.050 & $32.0(25 C)$ & 3.8 \\
\hline イソプロパノール & $\mathrm{i}-\mathrm{C}_{3} \mathrm{H}_{7} \cdot \mathrm{OH}$ & 0.7865 & 2.400 & 21.7 & 33 \\
\hline エチレン・グリコール & $\left(\mathrm{CH}_{2}\right)_{4} \cdot 0 \cdot\left(\mathrm{CH}_{2}\right)_{2}$ & 0.9020 & 3.460 & 27.3 & 0.76 \\
\hline モノブチルエーテル & $\mathrm{OH}$ & & & & \\
\hline ソルフィット & $\mathrm{CH}_{3} \mathrm{O} \cdot \mathrm{C}\left(\mathrm{CH}_{3}\right)_{2} \cdot\left(\mathrm{CH}_{2}\right)_{2} \cdot \mathrm{OH}$ & 0.9270 & 7.350 & 22.9 & 0.5 \\
\hline
\end{tabular}

（4）蒸発性が高い。

蒸気圧が高く蒸発速度も大きい。キャビテーション エネルギーもまた, 蒸気圧に関係し々の要因となっ ている。この結果, 乾燥時間が短縮できるわけであ る。仕上がり乾燥が良いといらことは, 大気中の于 リ，ホコリが付着しない。

（5）溶解能が高く脱脂力が強い。

相対的な溶解能力の目安として，カウリーブタノー ル值 (KB 值) といらのが用いられている。この值 が大きい方が溶解能力が大きい。

(6) 凝固しやすい。

再生回収が簡単である。

表 2 は, 溶剂として超音波洗浄用に利用される可能性の あるものの特性值である。

この資料からみると, エチルエーテルが粘度, 表面張 力および蒸気圧の面からみると, 超音波洗浄用溶剂とし ては最適であるが, 引火点が $-29^{\circ} \mathrm{C}$ と低いのが欠点で ある。

次に粘度, 表面張力拈よび蒸気圧の面からみると, メ チレンクロライドが適しており，第三位としてはフロン ソルブまたはフレオン TF が適している。しかしなが ら, 塩素系やフッ素系有機溶剂が多用されるにつれて, 酸欠事故の報告も目立つようになってきた。

\section{3. 有機溶剤の環境污染防止対策}

\section{1 塩素系溶剤}

従来, 大気污染に対する公害防止の規制があったが, これに加え最近排出抑制に対する規制が発表された。以 下これについて詳述してみる。

さて, 塩素系溶剤による地下水污染問題は, 1974 年米 国ニューオリンズ市に执いて水道水からトリハロメタン 等が検出されたことに端を発している。さらに，米国， 一部の $\mathrm{EC}$ 諸国 (英国, 西独捻よびオランダ) 等において 水道水からトリクロロエチレン等が検出されたために, WHO（世界保健機関）に扎い, この種の化学物質に 関するデータ収集亲よび安全性の検討が行われ，飲料水 にかかわる WHO の暫定ガイドラインを提示するに至 った。

我国に括いても昭和 56 年に八王子市, 川崎市, 府中 市などの水道水源用井戸水からトリクロロエチレン等が 検出された。環境庁が，全国主要都市 15 か所（東京都 を除く）の地下水を調査した結果，複数の都市において トリクロロエチレン等が検出された。その後も環境庁は 毎年 12 月に地下水污染実態調査結果を発表しているが, 污染は引き続き認められている。

この問題は，国会においても取りあげられ関係省庁に おいては，これに対応するためにトリクロロエチレン等 の排出抑制にかかわる関係法令の改正などを行った。 

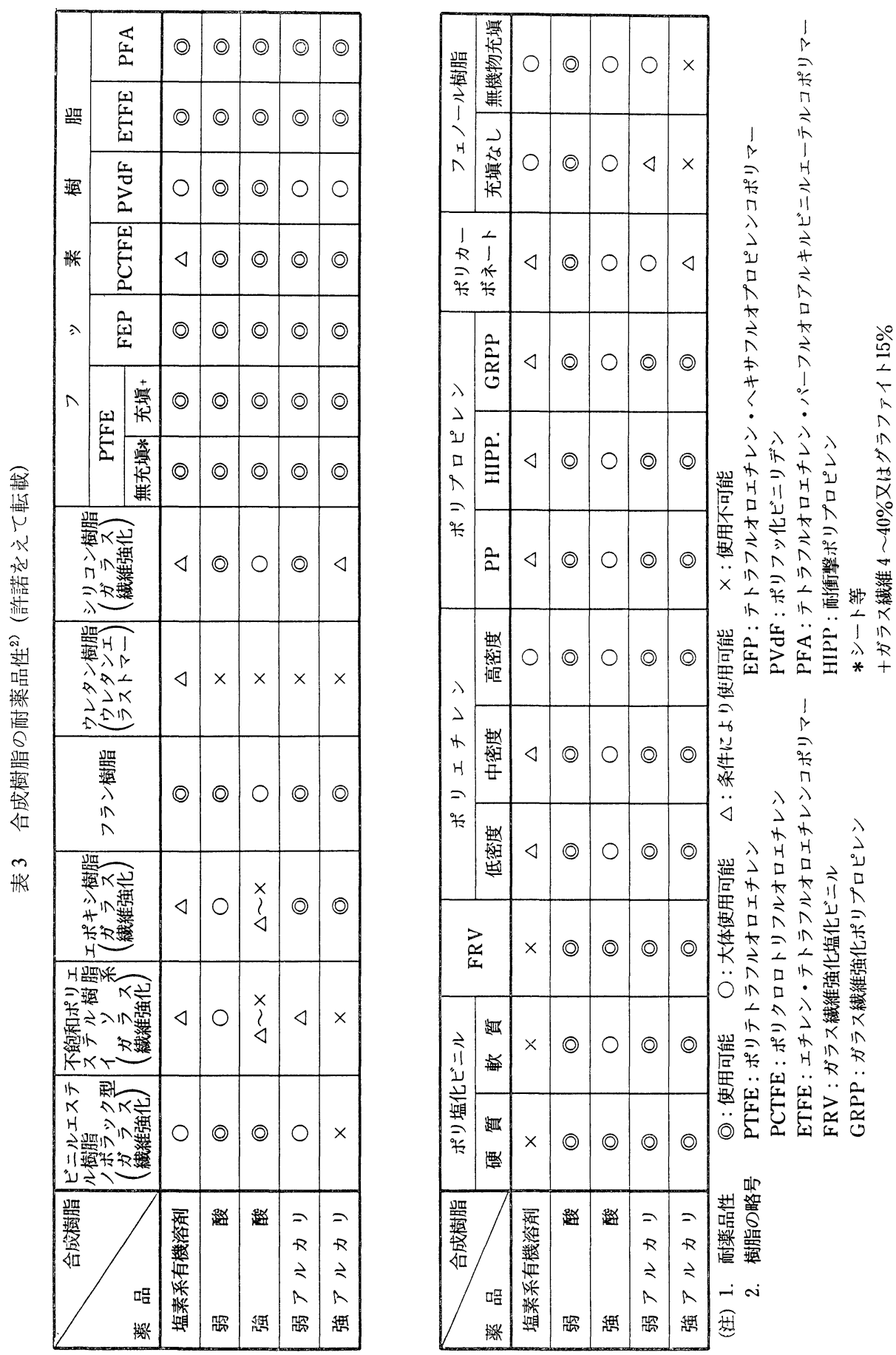
特飞, 昭和 61 年 5 月に「化学物質の審査特よび製造 等の規制に関する法律」(化審法）が改正され，これに基 づいてトリクロロエチレンおよびテトラクロロエチレン は昭和 62 年 5 月には「指定化学物質」に指定された。

さらにその後, “広範な地域にわたって相当程度の環境 污染が認められる”といら污染状況調査結果と“慢性毒

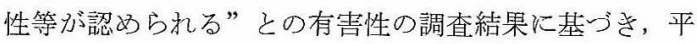
成元年 4 月 1 日に「第 2 種特定化学物質」に政令指定さ れた。これに伴い，環境污染を防止するための措置など に関する容器, 包装などに表示すべき事項拉よび技術上 の指針が同年 7 月に厚生省, 通産省から告示されたので ある。

なお，1，1，1ートリクロロエタンについては今回の改正 関係法令の規制の対象になっていないが，昭和 59 年の 暫定排水濃度目標（管理目標）を遵守寸る必要が丙る。

そこで，環境污染防止措置に関する技術上の指針を具 体的以説明すると，次のと怙りである2。

(1) トリクロロエチレン等を取り扱ら施設・場所につ いては, 次の事項に留意した構造とすること。

(a) 床面は,トリクロロエチレン等の地下浸透を適 切に防止出来るコンクリート等の材質とするこ と。また，そのひび割れ等が心配される場合には， トリクロロエチレン等に耐性をもつ合成樹脂によ る床面の被覆容器等の下へのステンレス鋼の受け 皿の設置等浸透防止措置をとること。表 3 は，合 成樹脂の耐薬品性を示するので㐫る。

（b）必要な場合には，取り扱らトリクロロエチレン 等の量及び作業に対応して, 施設・場所の周半に 防液是, 側溝又はためますを設置する等トリタ口 ロエチレン等の流出を防止する措置をとること。 また，雨水のかかる施設・場所及び水を使用する 施設・場所の周囲には，前記の措置に加えてトリ クロロエチレン等と水を適切に分離する分離槽を 設置すること。

(c) 施設 (配管などを含む) は地上に設置すること。 やむを得ず，地下とする場合には，地下ピット（床 面及び壁面は浸透防止ができるコンクリートが適 当である）内に置くこと。図 2 は好ましい貯蔵夕 ンクの例である。

(2) 貯蔵施設・場所に関する事項については次の之お りである。

（a）ドラム午等の容器で貯蔵する場命は次のことに 留意し，直射日光による温度上昇拈よび雨水によ る容器の腐食を防止すること。

(i) 貯蔵場所は屋内の冷暗所とすることが望むし いこと。

(ii) 貯蔵場所はやむを得ず屋外とする場合には屋

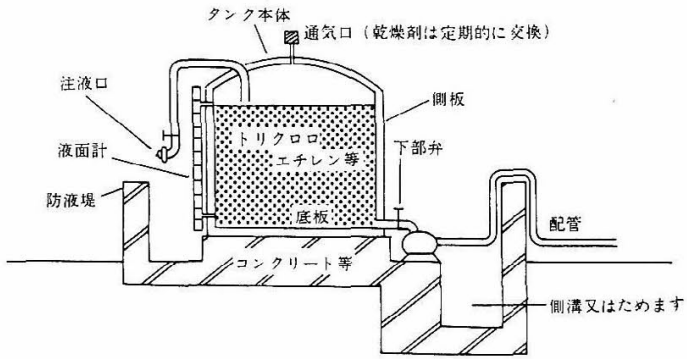

図 2 好をしい貯蔵タンクの例2)(許諾をえて転載)

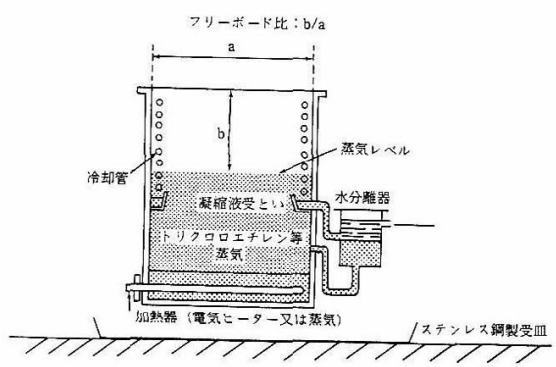

図 3 蒸気洗浄槽のフリーボード比 ${ }^{2)}$ (許諾をえて 転載)

根をつ忛る。容器にカバーをかける等の措置を 講じること。

（3）作業施設・場所に関する事項については次のと拉 りである。

(a) 原則としてトリクロロエチレン等の蒸気の発生 源を密閉できる構造とするか，または局部排気装 置を設置すること。

局部排気装置は，発生源から発生したトリクロ ロエチレン等の蓛気を全部吸い込ませ，その污染 空気をダクトで屋外へ排出する。必要に応じて活 性炭吸着装置等で污染空気中のトリクロロエチレ ン等を除去L., 排気を大気中に放出する。排気を大 気中に放出する局部排気装置の設置方法, 性能, 稼 動及び点検については有機溶剤中毒予防規則（第 14 条〜第 23 条）江定められている。

(b) 洗浄装置の開口部や溶剂の露出面積はできる限 り小さくすること。

(c) 洗浄装置のフリーボード比はできる限り大きく すること。

フリーボード比とは, 蒸気洗浄槽の場合は, 図 3 飞示すよう飞洗浄槽の短い方の開口寸法 (a) 飞対 する蒸気/空気境界から洗浄槽の上端までの高さ (深さ) (b)の比 (b/a) 学いう。委た，浸せさ洗浄 槽の場合は，洗浄槽の短い力の開口寸法 (a) 飞対 する溶剤の液面から洗浄槽の上端までの高さ（深 さ) (b) の比 (b/a) をいら。 
フリーボード比 $(\mathrm{b} / \mathrm{a})$ は, 蒸気洗浄槽では 0.5 以上, 常温浸せき洗浄槽では 0.7 以上が望まし く,フリーボード比は出来る限り大きくすること により, 洗浄槽からの溶剤の放出や蒸発に上る溶 剤損失を少なくすることができる。

（4）点検管理要領の策定等については, 次のとおりで ある。

（a）貯蔵施設・場所の点検管理は, 次の点に留意し て行うこと。

(i) 漏出の有無

(ii) コンクリート床面のひび割れ

(iii) 防液堤の損傷

(iv) 側溝, ためます, 分離槽等の状態

（v）荷積及の整理状況

(vi) その他

(b) 貯蔵施設の点検管理は次の点に留意して行うこ と。

(i) 底板の損傷, 腐食, 漏出の有無

(ii) 側板の損傷, 腐食, 漏出の有無

(iii) 液面計の損傷, 漏出の有無

(iv) 下部弁の損傷, 腐食, 漏出の有無

(v) 并の他

な抒，地下に設置されている場合には，構造的 に漏出の有無を確認しにくいため, 本体, 配管等 からの漏出の有無に留意し, 厳重な点検管理を行 らこと。

(c) ドラム午等の容器の点検管理は, 次の点に留意 して行うこと。

(i) 容器の損傷, 腐食, 漏出の有無

(ii) 栓のゆるみ

(iii) 貯蔵数量

(iv) その他

(d) 作業施設の点検管理については次のとおりであ る。

(i) 施設の本体,配管等の継目, 弁等からの漏出の 有無を点検管理すること。

(ii) 水分離器がある場合には, 管の詰まりおよび 水抜きの状態を点検管理すること。

(e) 作業場所の点検管理については次のとおりであ る。

(i) 床面, 受皿, 地下ピットへのトリクロロエチ レン等の漏出の有無を点検管理すること。

(ii) ためます, 分離槽等へのトリクロロエチレン 等の漏出の有無を点検管理すること。

(iii) 床面, 地下ピットのひび割れを点検管理する こと。

以上の点検項目, 頻度, 基準等を定め, 点検表により作
業開始ごと(始業点検), 作業中 (1 3 回/日随時点検), または定期的に点検を行ら必要がある。

(5)トリクロロエチレン等の取扱作業については, 次 の事項に留意して作業すること。

（a）作業要領を作成し，作業中にはこれを遵守させ ること。

（b）移替作業については，次の事項に注意すること。

(i) 適切に整備されたトリクロロエチレン等に適 した手動ポンプ又は自動ポンプを使用し，他 の溶剂と併用しないこと。

(ii) ポンプを使用しない場合は, サイホンを利用 する。

(iii) 移替作業は, トリクロロエチレン等を飛散又 は流出させないように行うこと。

(iv) 液面の高さに注意して, あふれることのない ようにする。

（v）使用装置に充填する場合は, 作業および使用 装置の作動を停止すること。

（vi）移替作業後, 直ちに注液口を密栓すること。

(vii) 万一䛊って漏出させた場合に備方, 移替作業に あたって受皿等を用意すること。

(c) 使用については, 次の事項に注意すること。

(i) 使用装置については, 始業点検を行うと共に 作業中にも随時点検を行うこと。

(ii) 水分離器等のフィルター等の交換は, トリク ロロエチレン等を十分に除去した後に行う。

(iii) 作業終了後は使用装置の点検を行い, 使用装 置をふたで密閉する等トリクロロエチレン等 の蒸発を防止すること。

(vi) 洗浄作業中, 冷却水の温度はできる限り低く すること(冷却水の入口温度は原則として $25^{\circ} \mathrm{C}$ 程度をこえないこと)。ただし, 湿度の高 い時は, 大気中の水分を多く凝縮させるため, 下げ過ざないこと。

（v）被洗浄物の移動は洗浄装置の蒸気層を乱さな い程度の速さで行う。

(iv) スプレー作業は, 原則として洗浄装置の蒸気 層内で行い，蒸気層内で行らことができない 場合には, 囲い式フード等の中で行らことと し,囲い式フード等からの排気は, 活性炭吸着 等によりトリクロロエチレン等を出来る限り 回収し, 再利用する。

(vii) 被洗浄物等にトリクロロエチレン等が残留し ないようにする。とくに, 次の工程で水を使 用する場合には, 水にトリクロロエチレン等 が溶解又は混入するため注意すること。

(viii) ウエス等を用いるふきとり洗浄作業等の場合 
にはトリクロロエチレン等を飛散又は流出さ せないように注意して作業を行う。万一, 䛊 って流出させた場合に備えて，ふき取り洗浄 作業に当たっては受皿等を使用すること。

（6）回収再利用については，次の事項が規定されてい る。

（a）活性炭吸着装置は, 活性炭の吸着効果を適正に 保持するため，活性炭が飽和状態になる前に適切 な間隔で再生を行ら。

(b) 吸着を停止した活性炭に水蒸気を送りこんでト リクロロエチレン等を脱着する際には, 使用する 水分離器の詰まり打よび水抜きに注意すること。

(c) 使用済みのトリクロロエチレン等の突沸及び分 解を防ぐために，蒸溜温度は適正な範囲に保持し て蒸溜を行う。トリクロロエチレンの蒸溜温度範 囲は $100 \sim 110^{\circ} \mathrm{C}$, テトラクロロエチレンの蒸溜 温度範囲は $130 \sim 140^{\circ} \mathrm{C}$ である。

（7）漏出処理については, 次の内容をふまえた漏出処 理要領を策定し, 応急措置, 処理方法をあらかじめ 作業者に周知して报くこと。

（a）発見者は,漏出を責任者に通報すると共に, 通報 を受けた責任者は，装置を停止させる等必要な応 急措置をすみやかに作業者に対し指示すること。

(b) 漏出箇所からの漏水を止めるか, 又はその施設 内の内容物を他の容器へ移しかえること。 （c）漏出物は,ポンプ等により回収を行い,またポン プ等により回収できなかったものについては，活 性炭等により吸着, 乾燥した砂等による吸収又は ウェス, 紙タオル等によるふさとりを行らこと。

(8)トリクロロエチレン等の排出処理については, 次 のごとく規定されている。

(a) 排出ガスは，活性炭による溶剤回収装置で処理 することにより,トリクロロエチレン等の濃度を 都道府県括よび政令指定都市の公害防止条例で定 める表 4 の排出規制基準以下に下げることができ る。

(b) 排水処理装置は, 排水の量及び含をれるトリク ロロエチレン等の濃度に応じて次のことに留意し て適切な構造と処理能力を有するものを設置する こと。

(i) 排水処理装置としては, 空気を吹き込むばつ 気式と活性炭による吸着式が一般的である が，これらは排水の実態に合わせて選定する 必要がある。

(ii) 排水処理は，処理の効率を上げる観点からで きる限り発生源の近くで行ら必要がある。

(iii) ばっ気式処理装置は, 排水量, ばっ気空気量, ばっ気時間等を適切に管理し，ばっ気不足を 生じさせない。なお, ばっ気式処理装置から の排気はトリクロロエチレン等を含も部た必

表 4 公害防止条例によるトリクロロエチレンなどの排出ガスの規制基準 ${ }^{2)}$ (許諾をえて転載)

\begin{tabular}{|c|c|c|c|c|}
\hline \multirow[b]{2}{*}{ 都道府県 } & トリ & クロ $\square$ チ & レン & テトラクロロエチレン \\
\hline & 排出口濃度 & $\begin{array}{l}\text { 敷地境界線上 } \\
\text { 濃 }\end{array}$ & $\begin{array}{l}\text { 地上到達点 } \\
\text { 濃 }\end{array}$ & 排出口濃度 \\
\hline 東 京 都 & $100 \mathrm{ppm}$ & & & $100 \mathrm{ppm}$ \\
\hline 神 奈 川 県 & $50 \mathrm{ppm}$ & & & $50 \mathrm{ppm}$ \\
\hline 愛 知 県 & $100 \mathrm{ppm}\left(540 \mathrm{mg} / \mathrm{m}^{3}\right)$ & & & $100 \mathrm{ppm}\left(680 \mathrm{mg} / \mathrm{m}^{3}\right)$ \\
\hline 大 阪 府 & $\begin{array}{c}\mathrm{C}=398 . \mathrm{S} / \mathrm{Q}^{*} \\
(30 \text { 分間值 })\end{array}$ & $\begin{array}{c}2 \mathrm{ppm}\left(12 \mathrm{mg} / \mathrm{m}^{3}\right) \\
(30 \text { 分間值) }\end{array}$ & & \\
\hline 兵 庫 県 & & $\begin{array}{c}\text { 2ppm } \\
\text { (30分間値) }\end{array}$ & $\begin{array}{c}\text { 0.7ppm } \\
\text { (30分間値) }\end{array}$ & \\
\hline 奈 良 県 & $\begin{array}{c}\mathrm{C}=408 . \mathrm{S} / \mathrm{Q}^{*} \\
(30 \text { 分間値) }\end{array}$ & $\begin{array}{c}2 \mathrm{ppm}\left(12 \mathrm{mg} / \mathrm{m}^{3}\right) \\
(30 \text { 分間値) }\end{array}$ & & \\
\hline 和 歌 山 県 & $140 \mathrm{ppm}$ & & $\begin{array}{c}0.7 \mathrm{ppm} \\
\text { (30分間値) }\end{array}$ & \\
\hline 川 崎 市 & & $\begin{array}{c}2 \mathrm{ppm}\left(12 \mathrm{mg} / \mathrm{m}^{3}\right) \\
(30 \text { 分間値) }\end{array}$ & & \\
\hline
\end{tabular}

(注) ${ }^{*} \mathrm{C}$ : 排出口基準濃度 $\left(\mathrm{mg} / \mathrm{Nm}^{3}\right)$
$\mathrm{S}: 23.1\left(\mathrm{H}_{0}-6\right)^{2}$
ただし $\mathrm{H}_{0}$ : 排出口の実高さ $(\mathrm{m})$
$\mathrm{Q}$ ：排出ガス量 $\left(\mathrm{m}^{3} / \mathrm{min}\right)$ 
要に応じ処理をする。

(iv) 活性炭式処理装置は, 活性炭の吸着効果を適 正に保持するため,トリクロロエチレン等を 吸着する活性炭が飽和状態になる前に，適正 な間隔で交換又は再生を行ら。な拉,この方 式では高濃度の排水に対しては処理能力が低 いことに注意する必要がある。

さて, 1, 1, 1-トリクロロエタン(メチルクロロフォルム) は,オゾン破壊係数が 0.1 で,フロン (CFC-11.1.0)にく らべると非常に小さい物質であるが, 1990 年 6 月のモン トリオール議定書の締約国会議（ロンドン会議）におい て規制強化のための議定書の改定案が採択され急に規制 対象物質に追加された。この改定された議定書に括いて， 1, 1,1ートリクロロエタンは次のようなスケジュールによ り規制されるごとになったのである。

$\begin{array}{ll}1993 \text { 年 } 1 \text { 月以降 } & 1989 \text { 年水準に凍結 } \\ 1995 \text { 年 } 1 \text { 月以降 } & 30 \% \text { 以上削減 } \\ 2000 \text { 年 } 1 \text { 月以降 } & 70 \% \text { 以上削減 } \\ 2004 \text { 年末すでに } & \text { 全廃 }\end{array}$

このような動さに応じて，この規制強化に対処するため には，次のような削減対策が必要である。

(1) 密閉型洗浄装置, 回収・再利用装置の導入による 排出抑制

（2）適正な使用及び管理方法の徹底

（3）積極的な代替品の使用，代替技術の開発利用

\section{2 フッ素系溶剤}

フロンが成層圏においてオゾン破壊の因をなしている との論議は, 1974 年カリフォルニア大学のローランド 教授によってはじめて唱えられ，その後，1985 年にオゾ ン層保護のためのウィーン条約を採択, 1987 年にはオ ゾン層を破壞する物質に関するモントリオール議定書を 採択, 1988 年には特定物質の規制等によるオゾン層の 保護に関する法律（フロン等規制法）を制定，公布。 1990 年のモントリオール議定書第 2 回締約国会議 (ロン ドン会議) ではフロンなどのオゾン層 破壊物質の 2000 年に全廃することが決定されたわけである。そしてこの 対策としては次の 3 つの方法がとられている。

(1) ノンフロン型の新溶剤の開発

(2) 混合フロンによる削減型溶剤の導入

（3）消費量削減対策のための装置の開発

以下, これらのらち特にノンフロン型の新溶剤につい て述べてみる。

(1) $\mathrm{EC}-7^{3)}$

テルペンクリーナーEC-7 は, 米国ペトロファーム社 により開発された。同社は, テルペン系溶剤のロジン残 椬除去能力に着目しこれに非イオン系界面活性剤を加え ることにより後洗浄での水によるすすぎを可能にしたも

\section{表 5 EC-7 の特性 ${ }^{3)}$ (許諾を兄て転載)}

\begin{tabular}{|c|c|c|}
\hline \multicolumn{2}{|l|}{ 外 観 } & 淡黄色透明 \\
\hline \multicolumn{2}{|c|}{ 比重 $\left(25^{\circ} \mathrm{C}\right)$} & 0.840 \\
\hline \multicolumn{2}{|l|}{ 凝固点 } & $-40^{\circ} \mathrm{C}$ \\
\hline \multicolumn{2}{|c|}{ 表面張力 } & 33 dyne $/ \mathrm{cm}$ \\
\hline \multicolumn{2}{|l|}{ 蒸気压 } & 1.6 torr \\
\hline \multicolumn{2}{|c|}{ 沸 点（最低） } & $172^{\circ} \mathrm{C}$ \\
\hline \multicolumn{2}{|c|}{ 蒸気密度 (空気 $=1$ ) } & $>1$ \\
\hline \multirow{2}{*}{ 引火点 } & $\mathrm{COC}$ & $71^{\circ} \mathrm{C}$ \\
\hline & TCC & $47^{\circ} \mathrm{C}$ \\
\hline \multicolumn{2}{|c|}{ 水への溶解 } & 馝 濁 \\
\hline \multicolumn{2}{|c|}{$5 \% \mathrm{pH}$} & $4 \sim 6$ \\
\hline
\end{tabular}

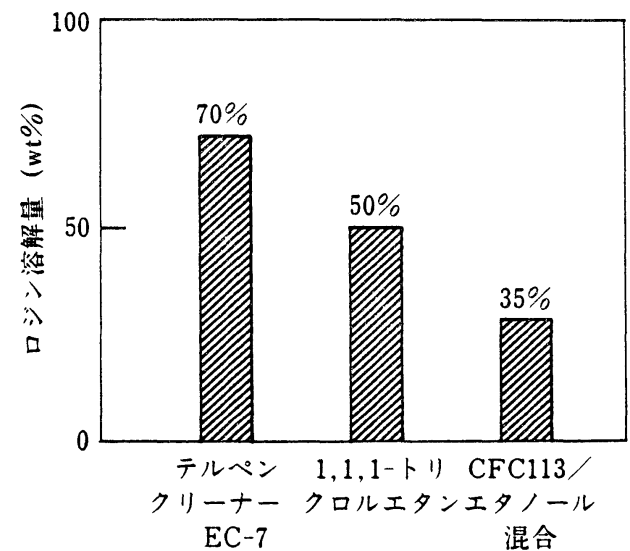

図 4 各溶剂のロジン溶解力 $\left(25^{\circ} \mathrm{C}\right)^{3)}$ (許諾をえて 転載)

のである。EC-7 は米国 AT \& T 社に括いて 2 年間にわ たって試験された。その結果, 洗浄力, 部品に対する電 気的特性に执いて十分満足なものであると報告されてい る。米国では Bioact EC-7 として商標登録されている。 テルペンクリーナーEC-7 のメリットをのベると次のと おりである。

(a) 塩素を含まず，オゾン層を破壊しない

EC-7 の主成分であるd-リモネンは, 分子式 $\mathrm{C}_{10} \mathrm{H}_{10}$ で表され，炭素と水素とからなる。塩素，臭素を持た ないためオゾン層破壞のメカニズムとは関係がない。

(b) 毒性や腐食性がない

EC-7 の成分は, いずれも既存物質であり, 毒性に いては問題はない。また, 表 5 のと括り EC-7 の pH は中性域に入っているため金属に対する腐食について は問題はない。

（c）生物分解性をもち, 排水処理が簡単

EC-7 が生物分解性をもつため, 排水処理は活性污 泥処理などで斉み特に複雑な処理を必要としない。 (d) 洗浄力が大きい 
表 6 ペフォールTM の物性比較表 ${ }^{4)}$ (許諾をえて転載)

\begin{tabular}{|c|c|c|c|c|c|}
\hline & $\begin{array}{r}\text { ペフォール } \\
5 \mathrm{PM}\end{array}$ & $\begin{array}{r}\text { ペフォール TM } \\
5 \mathrm{P}-\mathrm{W}\end{array}$ & $\begin{array}{r}\text { ペフォールTM } \\
5 \mathrm{P}-\mathrm{X}\end{array}$ & $\begin{array}{c}\text { S 3 } \\
(\text { (フロン113) }\end{array}$ & $\begin{array}{r}\text { 1,1,1-トリクロ } \\
\text { ロエタン }\end{array}$ \\
\hline 成 分 組 成 & $\begin{array}{c}\mathrm{C}_{3} \mathrm{~F}_{5} \mathrm{H}_{2} \mathrm{OH} \\
(5 \mathrm{FP})\end{array}$ & $\begin{array}{l}5 \mathrm{FP} / \text { 水 } \\
\text { 共沸混合物 }\end{array}$ & $\begin{array}{c}5 \mathrm{FP} / \\
\text { 界面活性㓮 }\end{array}$ & CFC-113 & $\mathrm{CH}_{3} \mathrm{CCl}_{3}$ \\
\hline な 用 途 & $\begin{array}{l}\text { 水溶性フラックス } \\
\text { の洗浄, 脱水乾燥 }\end{array}$ & $\begin{array}{l}\text { 水溶性フラックス } \\
\text { の洗浄, 脱水乾燥 }\end{array}$ & $\begin{array}{l}\text { ロジン系フラックス } \\
\text { の洗浄, 脱水乾燥 }\end{array}$ & 一般洗浄 & 一般, 油脂の洗浄 \\
\hline オゾン破壊指数 & ゼロ & ゼロ & ゼロ & 0.8 & 0.11 \\
\hline 温 暖 化 指 数 & ゼロ（推定） & ゼロ (推定) & ゼロ（推定） & $1.3 \sim 1.4$ & $0.02 \sim 3$ \\
\hline 分 & 150 & 104 & 158 & 187 & 134 \\
\hline 沸 & 80.7 & 77.3 & 81 & 47.6 & 74.1 \\
\hline 液 比重 $\left(25^{\circ} \mathrm{C}\right)$ & 1.510 & 1.466 & 1.405 & 1.561 & $1.349 *$ \\
\hline 粘 度 $\quad\left(25^{\circ} \mathrm{C} \mathrm{cp}\right)$ & 2.82 & 2.73 & 4.85 & 0.66 & $0.9 * *$ \\
\hline 表面張力 $\left(25^{\circ} \mathrm{C}\right)$ & 19 & 22 & 18 & 18 & $26 *$ \\
\hline 蒸発速度 $\left(\mathrm{CCl}_{4}=100\right)$ & 43 & 34 & 47 & 271 & 89 \\
\hline $\begin{array}{lll}\mathrm{K} & \mathrm{B} & \text { 値 }\end{array}$ & 36 & 33 & 43 & 31 & 124 \\
\hline 水の 溶 解 度 （\%) & 11.8 & 6.6 & 10.2 & 0.011 & 0.05 \\
\hline 引 火 点 & なし & なし & なし & なし & なし \\
\hline 化 審 法官 報 番 号 & $2-3364$ & $2-3364$ & 2-3364/認可品 & $2-95$ & $2-55$ \\
\hline
\end{tabular}

表 7 毒性比較表 ${ }^{4}$ （許諾をえて転載）

\begin{tabular}{|c|c|c|c|c|c|c|c|}
\hline \multirow[b]{2}{*}{ 洗 浄 剈 名 } & \multicolumn{3}{|c|}{ 動物：ラット } & \multicolumn{3}{|c|}{ 動物:マウス } & \multirow{2}{*}{$\begin{array}{l}\text { USA } \\
\text { 許容 } \\
\text { 濃度 } \\
(\mathrm{ppm})\end{array}$} \\
\hline & $\begin{array}{c}\text { 吸入毒性值 } \\
\text { LC50（ppm） }\end{array}$ & $\begin{array}{l}\text { 同左値 } \times H \\
\text { 単位 千 }\end{array}$ & $\begin{array}{c}\text { 経口毒性 LD50 } \\
(\mathrm{mg} / \mathrm{kg})\end{array}$ & $\begin{array}{c}\text { 吸入毒性值 } \\
\text { LC50 (ppm) }\end{array}$ & $\begin{array}{l}\text { 同左值 } \times \mathrm{H} \\
\text { 単位 } \neq\end{array}$ & $\begin{array}{c}\text { 経口毒性 LD50 } \\
(\mathrm{mg} / \mathrm{kg})\end{array}$ & \\
\hline ペフォール ${ }^{\mathrm{TM}} 5 \mathrm{P}$ & $4,140(4 \mathrm{H})$ & 16.6 & 1,960 & ALC $7,000(2 \mathrm{H})$ & & & \\
\hline アルコール類 & & & & & & & \\
\hline シフッ化エタノール & $550(6 \mathrm{H})$ & 3.3 & 240 & $710(2 \mathrm{H})$ & 1.4 & 365 & 2.5 \\
\hline 四フッ化プロパノール & ALC $2,000(4 \mathrm{H})$ & 8.0 & ALC 3,400 & & & & \\
\hline エタノール & $20,000(10 \mathrm{H})$ & 200.0 & 7,060 & $20,300(4 \mathrm{H})$ & 81.2 & 7,800 & 1,000 \\
\hline イソプロパノール & $16,000(8 \mathrm{H})$ & 160.0 & 5,045 & & & & 400 \\
\hline 塩素系 & & & & & & & \\
\hline 1,1,1ートリクロロエタン & & & 10,300 & LCLo $11,000(2 \mathrm{H})$ & 22.0 & 11,240 & 350 \\
\hline トリクレン & LCLo $8,000(4 \mathrm{H})$ & 32.0 & 7.190 & LCLo $3,000(2 \mathrm{H})$ & 6.0 & & $\star 50$ \\
\hline パークレン & LCLo $4,000(4 \mathrm{H})$ & 16.0 & 8,850 & LCLo $3,300(2 \mathrm{H})$ & 6.6 & 8,100 & 50 \\
\hline 芳香族系 & & & & & & & \\
\hline ベンゼン & $10,000(7 \mathrm{H})$ & 70.0 & 4,894 & & & 4,700 & $\star \star 10$ \\
\hline トルエン & LCLo $4,000(4 \mathrm{H})$ & 16.0 & 5,000 & $5,320(8 \mathrm{H})$ & 42.6 & & 100 \\
\hline キシレン & $5,000(4 \mathrm{H})$ & 20.0 & 4,300 & & & & 100 \\
\hline
\end{tabular}

ペフォール TM $5 P$ : ラット…日本パイオアッセイ研究センターでの測定值

マウス…当社の測定值

四フッ化プロパノール：Handbook of experimental pharmacology (1966)

他: Registry of toxic effects of chemical substances (1986)

LC50:50\%致死吸入浱度 ALC: $50 \%$ 致死概算吸入㵒度 LCLo: $50 \%$ 以下致死吸入濃度

L D50：50\%致死経口投与量 ALC：50\%致死概算経口量

: 動物発癌性 $\star$ : 人体発癌性 
$d$-リモネンの構造式はロジンの主成分であるアビエ チン酸の構造式と類似している。そのため, 相互溶解 性が非常に高く, 図 4 亿示す通り EC-7 は CFC 113/ エタノール混合物の約 2 倍のロジン溶解性をもつ。ま た，溶解スピードもそれに応じた速さをもつものであ る。

(e) 液ライフが長く, 長期使用が可能

CFC 113 と比較すると, EC-7 は蒸発によるロスが 殆んどなく、また液の老化があまり無いためロジンの 溶解能とあいまって長期使用が可能である。

(2) ペフォール4)

ダイキン工業（株）にて開発されたノンフロン型の洗 浄剤にて，その特徵は次のと抢りである。

(a) オゾン破壊能 (ODP) がゼロで, オゾン層を破壊 しない。

(b) 不燃性で, 引火, 爆発の危険がない。

(c) 表面張力が小さい $(19 \sim 22$ dyne/cm)

（d）化学物質の審査及び製造等の規制関する法律 （化審法）の既存化学物質として登録済みである

(No. 2-3364)。

ペフォールの物性比較表を表 6 亿示す。また,ペフォ ールの毒性については検討中との事であるが, 現在まで に判明しているデータを関係化合物と比較したるのは表 7 のと抢りである。

皮膚拈よび眼粘膜に対する刺戟性テストの結果は次の
ごとく報告されている。

（a）皮膚に対する刺戟性

ペフォール 5P，フロン 113 ，トリクロロエタンは 中等度刺戟物であり, ゚゚ォール P-W は弱い刺戎 5物である。

(b) 眼粘膜に対する刺戟性

ペフォール5P は中等度刺戟物であり,トリクロ ロエタンは軽度刺戟物である。

(3) パインアルファ ST-900 シリーズ5)

荒川化学工業株式会社が開発したフロン 113 の代替品 である。この開発に当たっては，高洗浄力や高引火点ま たはプラスチックダメージが小さいといった洗浄剤の基 本特性に加光，次の方針を重視したのである。

(a) 酸, 塩基, 塩類などのイオン性物質やハロゲン化 物を含まないこと

(b) 労働安全衛生法の関連規制に規制されている物質 を含まないこと

（c）新規に合成されたものや特定用途にのみ用いられ ている化合物，または安定して入手出来ない天然物 などを使用しないこと

（d）人体や環境に対して影響の少ない化合物を用いる こと

この方針にて開発されたパインアルファST-900 シリ 一ズの一般物性を表 8 に掲げる。この表から判明するよ 万に引火点が高く, 消防法の危険物には第 3 石油類 (S-T

表 8 一般物性 ${ }^{5}$ ) (許諾を兄て転載)

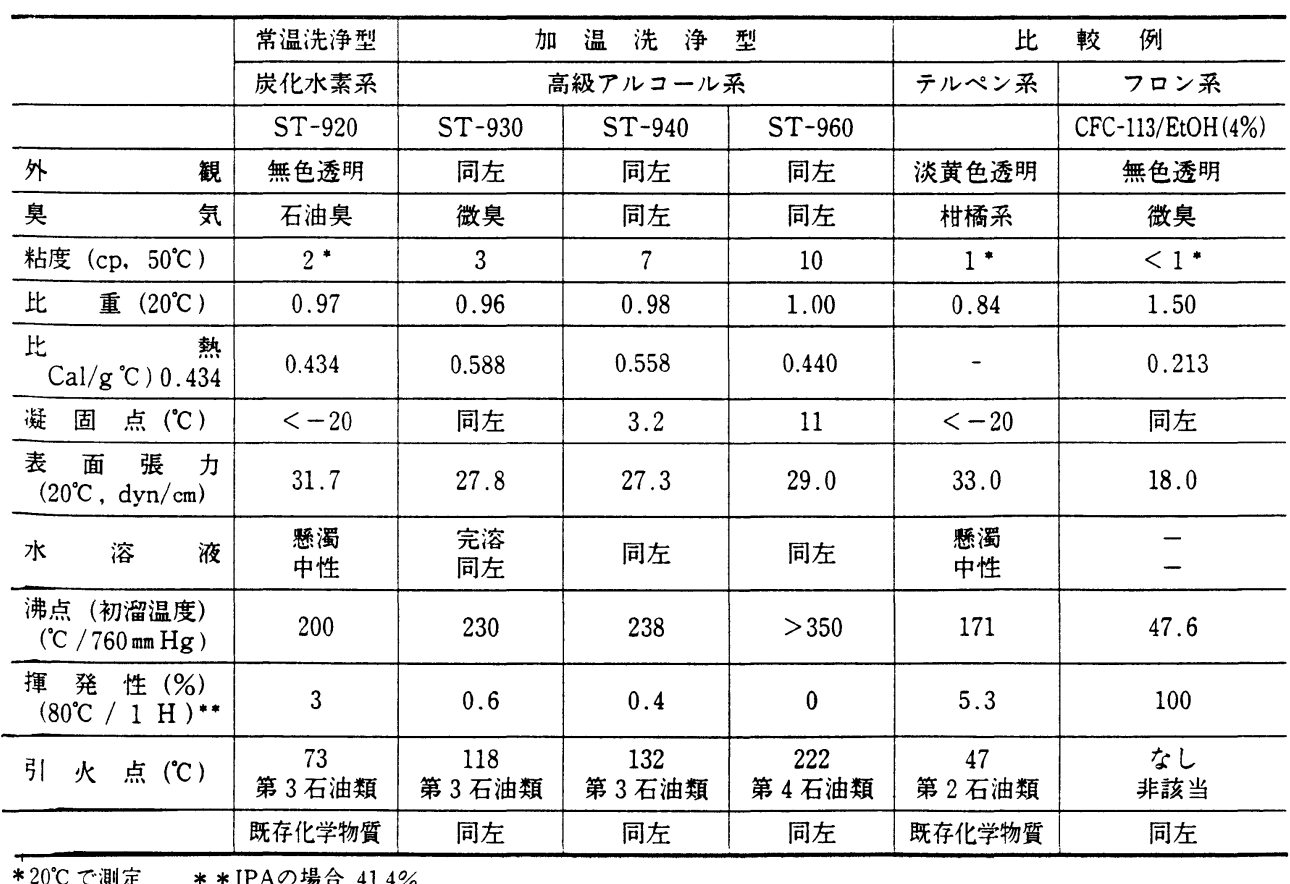


920，930，940）または第 4 石油類（ST-960）に分類され る。とくに, 加温洗浄タイプの ST-930, 940, 960 では使 用温度 $60^{\circ} \mathrm{C}$ と引火点との温度差が約 $60^{\circ} \mathrm{C}$ 以上でめり 安全性は高いといえる。

(4) エタノール

通産省では昭和 63 年度から平成 2 年度屯での 3 か年 計画で, フロン 113 の代替洗浄剤としてのエタノールの 可能性を検討するため, 調査研究を社団法人アルコール 協会に委託した。これまでの研究から,かなりの洗浄効 果があることが判明したので, 現在消防法の規制対象外 である $60 \%$ エタノールを中心として保安, 洗浄力高度 化等の要素技術を組み合わせたシステム最適化の研究を 実施している。中間の評価としては，エタノールの洗浄 力はステンレス板等の油性污れに対してはフロン 113 よ り優れた洗浄効果がある，プリント基板等のハンダフラ ックス污れに対してはすぐれた洗浄効果がある，ガラス 板等の粒子污れに対しても相当の効果が期待出来るなど である。今後は污れの種類, 洗浄材料, 保安対策, 排水 処理等を勘案したエタノールを用いた最適洗浄システム 装置の開発がまたれるわけである。

以上, ノンフロン型の新溶剂の開発状況であるが勿論 これ以外にも種及検討が加えられている。一方, 混合フ ロンによる削減型溶剤も導入されているが，基本的には オゾン破壊能 (ODP) がゼロでなければならないと考え られる。

\section{3 芳香族系溶剂}

一般的に芳香族系溶剤は, 臭気が強く,引火点が低く, 可燃性であり, 有害性も高い。また, 皮膚の荒れも強い。 よって, 芳香族系溶剤を使用する場合には火災の危険を 考慮し, 溶剤の選択, 設備, 排気などを慎重にする必要 がある。また，溶剤洗浄設備の周囲近辺には消火設備を 配置する必要がある。

\section{4. ま とめ}

有機溶剤清浄の種類とこれに用いられる溶剤について JIS Z 0303,「さび止め包装方法通則」に基づいて説明し， これに関連する環境污染対策とフロン対策に伴らノンフ ロン型新溶剤の動向について解説をした。

今後，塩素系溶剤の生産規制がすすすすきびしくなる 傾向が思考される現在，この一文が読者に対し少しでも 参考になれば筆者として望外の喜びとするところであ る。

(Received July 31, 1990)

\section{文献}

1）間宮富士雄：金属の洗浄 地人書館, (1972).

2) クロロカーボン衛生協会：トリクロロエチレン 又はテトラクロロエチレンの適正使用マニュアル (1989).

3) 伊東幸夫：Surface Control \& 洗浄設計, No. 46 (1990).

4) 古高靖久：同上.

5）千原真知夫：同上. 